\title{
WYKAZ PRAC DYPLOMOWYCH NAPISANYCH POD KIERUNKIEM KS. PROF. DRA HAB. EDWARDA STAŃKA
}

\section{A. Prace doktorskie}

1. Panuś K., Ideat chrześcijanina i metody jego realizacji $w$ „Mowach” św. Leona Wielkiego, 1989.

2. Kałdon S. OP, Pobożność maryjna i jej rola $w$ kształtowaniu postawy chrześcijanina w kazaniach O. Konstantego M. Żukiewicza OP, 1992.

3. Obirek S. SJ, Wizja Kościoła i państwa w kazaniach ks. Piotra Skargi SJ, 1994.

4. Świder R., Ideał chrześcijanina w kazaniach ks. Piotra Semenenki, 1995.

5. Żelazny J., Chrystus - Najwyższy Kapłan. Studium chrystologiczne na podstawie „Homilii” św. Jana Chryzostoma do Listu do Hebrajczyków, 1995.

6. Nowak J., Aktualność kaznodziejskiej koncepcji kształtowania sumienia w polskich kazaniach katechizmowych okresu międzywojennego, 1996.

7. Ślusarczyk F., Ideał chrześcijanina i sposób jego realizacji w kaznodziejskim przekazie abpa Józefa Bilczewskiego (1860-1923), 1997.

8. Guzdek J., Koncepcja narodu i jego wolności w kaznodziejskim przekazie ks. Hieronima Kajsiewicza, 1998.

9. Wróbel R. OFMConv, ,,Uciszenie burzy” (Mk 4, 33-41) w polskim przepowiadaniu posoborowym. Studium biblijno-homiletyczne, 1999.

10. Mateja L., Historyczne uwarunkowania ksztattowania doktryny o miłosierdziu. Studium dzieł Tertuliana i św. Cypriana, 2002.

11. Kaczmarek S., Darowanie win. Orygenesowa egzegeza przypowieści o nielitościwym dtużniku (Mt 18, 23-35) i wezwania Modlitwy Pańskiej (Mt 6, 12; Łk 11, 4) wraz z jej uzupetnieniem (Mt 6, 14-15), 2004.

12. Mrowiec T., Postuga słowa droga zamieszkania Boga w człowieku. Studium „Homilii św. Augustyna na Ewangelie i Pierwszy List św. Jana”, 2006.

13. Babiarz G., Grzech i nawrócenie w życiu ochrzczonych. Studium Komentarza Ambrozjastra do Listów św. Pawła, 2006.

14. Pochwat J. MS, Sprawiedliwość i miłosierdzie. Studium „Kazań do ludu”św. Cezarego z Arles, 2007.

15. Sordyl K., Pojęcie Boga w „De Trinitate”. Polemiczne aspekty teologii Nowacjana. 2007.

16. Ościłowski K. OSPPE, Ideał chrześcijanina i jego realizacja. Studium pism św. Paulina z Noli, 2008. 


\section{B. Prace licencjackie}

1. Bielas L., Postawa Juliana Apostaty wobec religii. Studium mów Grzegorza z Nazjanzu, 1985.

2. Duźniak P., Zarzuty Juliana z Eklanum przeciw Augustynowi. Studium traktatu ,Contra Julianum”, 1985.

3. Panuś K., Św. Patryk wzorem chrześcijańskiego misjonarza, 1985.

4. Baron A., Lacińskie komentarze okresu patrystycznego Listu św. Pawła do Tytusa. Studium porównawcze, 1987.

5. Panuś T., Chrześcijanin w obliczu śmierci na podstawie dziet św. Cypriana, 1988.

6. Ptasznik P., Tajemnica Kościoła w nauczaniu ks. bpa Jana Pietraszki, 1989.

7. Świder R., Nauka św. Augustyna o miłosierdziu Boga w „Objaśnieniach Psalmów", 1989.

8. Nowak J., Jan Pawet II nauczycielem modlitwy. Studium przemówień papieskich wygloszonych podczas trzech pielgrzymek do ziemi ojczystej, 1990.

9. Ślusarczyk F., Tajemnica Kościoła w kazaniach ks. Mariana Morawskiego SI, 1990.

10. Pochwat J. MS, Teksty o Abrahamie w pismach egzegetycznych Starego Testamentu Orygenesa, 1991.

11. Uciecha A., Nauka o wadach i cnotach w Homiliach św. Jana Chryzostoma na Pierwszy list do Koryntian, 1991.

12. Zagrodzki W., Sposób prowadzenia misji ludowych przez Zgromadzenie Najświętszego Odkupiciela po Soborze Watykańskim II, 1991.

13. Żelazny J., Soteriologiczny aspekt chrystologii św. Jana Chryzostoma na podstawie jego Homilii do Listów św. Pawła, 1991.

14. Solak A., Aktualność ideału kaptana w ujęciu św. Grzegorza Teologa, 1992.

15. Brendza G., Evanjelium ako cesta zivota v dielach Apostolskych Otcov, 1994.

16. Krupnik T. OCD, Modlitwa w ujęciu Ojców Pustyni. Studium porównawcze „Ksiegi Starców” i ,Rozmów” Jana Kasjana, 1994.

17. Sikorski L., Wezwanie do miłości Boga i bliźniego w przepowiadaniu św. Rafała Kalinowskiego, 1994.

18. Sławeński R., Kierownictwo duchowe w pasterskiej postudze kapłana wedtug „Księgi reguly pasterskiej” św. Grzegorza Wielkiego, 1994.

19. Urbanec B., Ideal krestanskiej dokonalostii u svateha Augustina v knihe „O reci Pana na verchu”, 1993.

20. Zyzak W., Sposób przedstawienia cierpień Chrystusa w „Objaśnieniach Psalmów" św. Augustyna, 1994.

21. Vojtasak V., Porovnanie idealu knaza w exerciciach Stefana Kluberta a v adhortacii „Pastores dabo vobis”, 1994.

22. Chmieliński L., Chrześcijanin w świecie w świetle wielkopostnych konferencji radiowych ks. arcybiskupa Józefa Teodorowicza pt. „,Kuszenie Chrystusa”, 1996. 
23. Gąsior P., Ideat młodego chrześcijanina i metody jego realizacji. Studium rekolekcji akademickich Stugi Bożego księdza Biskupa Jana Pietraszki, 1996.

24. Guzdek J., Wizja wolności człowieka w nauczaniu ks. bp J. Pietraszki, 1996.

25. Miśniak R., Teologiczny wymiar kazań ks. Jana Bazana (1905-1980), 1996.

26. Tomkiewicz W., Bogactwo źródet $w$ maryjnych kazaniach $i$ listach pasterskich arcybiskupa Jerzego Ablewicza, 1996.

27. Wylęgała M. OP, Doświadczenia Boga w przeżyciu „,misterium tremendum” w „Homiliach na List do Rzymian” św. Jana Chryzostoma, 1996.

28. Vitko S., Sekuláryzácja v Živote Kňaza podlá duchovnych cvičeni Stefana Kluberta, 1997.

29. Kida K., Bogactwo sakramentów w kaznodziejskim ujęciu brata Juliana Michalca, 1997.

30. Durlak L., Miłość zasada życia chrześcijańskiego. Studium kazań Cezarego z Arles, 1998.

31. Mateja L., Nauka o Duchu Świętym. Studium Homilii św. Augustyna na Ewangelię św. Jana, 1998.

32. Juszczyszyn L., Elementy patriotyczne w kazaniach i homiliach ks. Tadeusza Olszańskiego CM, 1998.

33. Wróblewski M., Recepcja adhortacji apostolskiej „,Reconciliatio et paenitentia”w przekazie „,Biblioteki Kaznodziejskiej” w latach 1985-1996, 1999.

34. Zelek J. OCist., Bóg, świat, człowiek w „Mowach” Grzegorza z Nazjanzu, 2000.

35. Kaczmarek S., Eklezjalny wymiar pokuty w „Listach” Bazylego Wielkiego, 2001.

36. Zarębski P., Soteriologia „, Wielkiej Katechezy” św. Grzegorza z Nyssy, 2002.

37. Klajman S., Eklezjologia Leona Wielkiego. Studium „Mów”, 2003.

38. Babiarz G., Łaska i wolność w ujęciu św. Jana z Damaszku. Studium „, Wykładu wiary prawdziwej”, 2003.

39. Szczerba Cz., Symbole $i$ obrazy biblijne $w$ „,Homiliach na Ewangelie” św. Grzegorza Wielkiego, 2004.

\section{Prace magisterskie}

1. Nowak J., Funkcje kapłańskie w dziele Jana Chryzostoma „, O kapłaństwie”, 1975.

2. Włoch K., Wady kobiet $w$ duszpasterskim spojrzeniu Cypriana biskupa Kartaginy, 1975.

3. Wróbel J., Funkcje kapłańskie w świetle homilii św. Jana Chryzostoma na Listy pasterskie św. Pawła, 1975.

4. Polak S., Rozprawa ks. J. Roztworowskiego pt. Charakter i znaczenie biskupstwa w pierwszych dwu wiekach dziejów Kościoła w świetle krytyki ks. Wt. Grzelaka, 1976. 
5. Trzop A., Najnowsze przepisy o szafarzu bierzmowania w świetle studium ks. Wt. Grzelaka - „Kaplan w roli szafarza bierzmowania”, 1977.

6. Buchinger R., Autorytet hierarchii kościelnej wedtug Ignacego z Antiochii, 1978.

7. Panuś K., Schemat dziejów ludzkości w „De Civitate Dei” św. Augustyna, 1979.

8. Byrski J., Teologiczna interpretacja pierwszych trzech próśb Modlitwy Pańskiej u Ojców Kościoła Zachodniego od Tertuliana do Augustyna, 1979.

9. Kozak T., Post w ujęciu Leona Wielkiego, 1979.

10. Kozieł S., Duszpasterskie podejście do prześladowania wedtug św. Cypriana, 1979.

11. Guzdek J., Katechizm dla dorostych. „Wielka katecheza” św. Grzegorza z Nyssy i „Podręcznik dla Wawrzyńca” św. Augustyna. Studium porównawcze, 1981.

12. Matuszek R., Duszpasterski charakter dyscypliny pokutnej Kościoła Wschodniego w świetle Listów Bazylego Wielkiego, 1981.

13. Polonka M., Sprawiedliwość i jej zwiazek z innymi cnotami w „De officiis” Ambrożego, 1981.

14. Bendyk M., Chciwość w „Homiliach” św. Bazylego Wielkiego, 1982.

15. Cichoń T., Stosunek Papieża Zozyma do pelagianizmu, 1982.

16. Koniorczyk K., Moc i mądrość Stwórcy objawiona w dziele stworzenia wedlug Heksameronu św. Ambrożego, 1982.

17. Kubasiak W., Poczatki pelagianizmu wedtug „Commonitorium super nomine Caelestii" Mariusza Merkatora, 1982.

18. Kościelny L., Moralny aspekt Homilii na Heksameron św. Ambrożego, 1982.

19. Mika S., Podejście św. Ambrożego do pokuty w traktacie „De paenitentia”, 1982.

20. Wanat M., Wartość religii chrześcijańskiej w Apologii Teofila Antiocheńskiego „Do Auktolyka”, 1982.

21. Sławeński R., Obraz Abrahama w Listach św. Hieronima, 1983.

22. Nowak Z., Wierzacy a niepraktykujący. Studium nad traktatem św. Augustyna „De fide et operibus”, 1983.

23. Skwierawski K., Przypowieść o Synu marnotrawnym w interpretacji Ojców tacińskich do św. Augustyna, 1983.

24. Biskup Z., Podstawowe prawdy chrześcijańskiej wiary w interpretacji św. Cyryla Jerozolimskiego, 1984.

25. Konieczny J., Chrześcijańskie podejście do śmierci w Listach kondolencyjnych św. Hieronima, 1984.

26. Panuś T., Duszpasterz w oczach Ambrozjastra. Studium nad komentarzem do II Listu św. Pawła do Tymoteusza, 1985.

27. Gawlik B.A., Modlitwa w ujęciu Ojców Pustyni na podstawie „Księgi Starców”, 1985.

28. Zuber J., Modlitwa w ujęciu św. Ambrożego, 1985. 
29. Czulak A., Dzieje Kościoła Antiocheńskiego do roku 313 na podstawie „Historii Kościoła” Euzebiusza z Cezarei, 1985.

30. Żak M., Nauka Ojców Apostolskich o szatanie i jego działaniu, 1985.

31. Zątek H., Stosunek chrześcijaństwa do wartości doczesnych w Homiliach św. Jana Chryzostoma na I List św. Pawła do Tymoteusza, 1985.

32. Klajman S., Dzieje Kościoła Aleksandryjskiego do roku 312 na podstawie „Historii Kościoła” Euzebiusza z Cezarei, 1985.

33. Baron A., Ideat duszpasterza. Studium w oparciu o Komentarz Pelagiusza do Listu do Tytusa, 1985.

34. Baron A., Św. Jan Chrzciciel $w$ „Komentarzu na Ewangelię św. Jana” Orygenesa, 1986.

35. Pochwat J., Wiara i madrość wedtug komentarza Pelagiusza do Listu św. Pawła do Efezjan, 1986.

36. Klimara A., Modlitwa „Ojcze nasz” w interpretacji Maksyma Wyznawcy, 1986.

37. Mańkowska H.A. CFrSJ, Święty Józef w pismach Augustyna, Biskupa Hippony, 1986.

38. Duraj J., Trudności w przekładzie Pisma Świętego na podstawie Listów św. Hieronima, 1987.

39. Nosek T., Angelologia i demonologia w ujęciu Teodoreta z Cyru. Studium traktatu „Leczenie chorób hellenizmu”, 1987.

40. Dybski H. OSB, Modlitwa w ujęciu św. Jana Kasjana, 1987.

41. Mrowiec T., Pismo Święte i jego interpretacja $w$,Filokalii” Orygenesa, 1987.

42. Filipek L., Dzieje św. Jana Chryzostoma w ujęciu Hermiasza Sozomena, 1987.

43. Gaweł R., Wyższość religii chrześcijańskiej w zestawieniu z religiami pogańskimi na podstawie Apologetyka Tertuliana, 1987.

44. Bercal S., Sylwetka św. Atanazego na podstawie „Historii Kościoła” Hermiasza Sozomena, 1987.

45. Kraj T., Stosunek mnichów do pracy wedtug „,Księgi Starców”, 1987.

46. Ptasznik P., Dzieje Ariusza wedtug ,,Historii Kościoła” Hermiasza Sozomena, 1987.

47. Płachta Z., Dzieje św. Atanazego bpa Aleksandrii w ujęciu Sokratesa Scholastyka, 1987.

48. Morawski R., Angelologia i demonologia w ujęciu św. Justyna Apologety, 1987.

49. Midor S., Miłosierdzie Boga i ludzi według Homilii św. Jana Chryzostoma na List św. Pawła do Filipian, 1988.

50. Kasperkiewicz M., Wypowiedzi o św. Janie Chrzcicielu Augustyna bpa Hippony w „Homiliach na Ewangelię św. Jana”, 1988.

51. Kościelniak W., Duszpasterskie podejście do kobiet $w$ Homiliach św. Jana Chryzostoma na Listy Pasterskie św. Pawła i na List do Filemona, 1988. 
52. Sobala M.D.CSSF, Warunkidobrejkatechezywedtugśs. Cyryla Jerozolimskiego, 1988.

53. Dziadosz R., Problematyka Listów św. Grzegorza z Nazjanzu do Bazylego Wielkiego, 1989.

54. Cupryś B.K. CSSF, Teksty mówiące o kobietach w „Historii Kościelnej” Euzebiusza, 1989.

55. Klauzner J., Reinkarnacja i zmartwychwstanie w ujęciu Grzegorza z Nyssy, 1989.

56. Bielak Cz., Potrzeba wyrzeczenia w ujęciu Doroteusza z Gazy, 1990.

57. Bieńkowski S. OFM, Rola opata $w$ zgromadzeniu zakonnym na podstawie „Listów” Grzegorza Wielkiego, 1990.

58. Dyrda P. OP, Stosunek wolnej woli do łaski na podstawie traktatu św. Augustyna „De gratia et libero arbitrio”, 1990.

59. Midor K., Nauka o wadach i grzechach w Pismach Ojców Apostolskich, 1990.

60. Konieczny P., Wyższość chrześcijaństwa nad religiami pogańskimi wedtug Minucjusza Feliksa, 1990.

61. Firszt D., Nauka św. Augustyna o chrzcie w „Homiliach na Ewangelie św. Jana”, 1990.

62. Kordula B., Św. Hieronim obrońca dziewictwa Najświętszej Maryi Panny. Studium traktatu ,Przeciw Helwidiuszowi”, 1990.

63. Bielawski M. OSB, Nauka św. Augustyna o grzechu na podstawie Homilii na Ewangelie św. Jana, 1990.

64. Wcisło R., Ideat mnicha w Listach św. Bazylego Wielkiego, 1990.

65. Tyrała R., Wiara, nadzieja, mitość w tekstach Ojców Apostolskich, 1990.

66. Niemiec W., Duszpasterska postawa Teodoreta z Cyru. Studium z „Listów”, 1990.

67. Prus W., Polemika z żydami i chrześcijanami na podstawie dzieł apologetycznych Flawiusza i Orygenesa, 1990.

68. Tokarz Z., Obraz Najświętszej Maryi Panny w homiliach i rozważaniach księdza biskupa Jana Pietraszki, 1991.

69. Gibała J., Nauka św. Grzegorza Wielkiego o mitosierdziu w jego „Homiliach na Ewangelie", 1991.

70. Dziuba M., Interpretacja przypowieści z Ewangelii św. Mateusza whomiliach księdza biskupa Jana Pietraszki, 1991.

71. Ligęza S., Nauka o miłości w kazaniach ojca Mateo, 1991.

72. Strachanowski M., Zagrożenia współczesnego człowieka ukazane w homiliach księdza biskupa Jana Pietraszki, 1991.

73. Żelazny J., Udziat Teodoreta z Cyru w sporach chrystologicznych w V wieku na podstawie jego „Listów”, 1991.

74. Caputa A., Obraz zmartwychwstalego czlowieka w „De civitate Dei” św. Augustyna, 1991. 
75. Gąsior P., Pierwotna godność człowieka w ujęciu św. Grzegorza z Nazjanzu, 1991.

76. Lubaszka S., Pojęcie Boga w „,Filokalii” Orygenesa, 1991.

77. Szydło J., Nauka św. Metodego z Olimpu o matżeństwie w „Uczcie dziesięciu dziewic", 1991.

78. Uniwersał L., Przepowiadanie Słowa Bożego w ujęciu św. Grzegorza z Nazjanzu, 1991.

79. Kochanowicz B. OP, Nauka o Matce Bożej w „,Mowach” św. Leona Wielkiego na tle jego poprzedników, 1991.

80. Grzelczak M. OP, Teologiczne wątki w „,Mowie świątecznej na budowanie kościołów” wygłoszonej przez Euzebiusza z Cezarei, 1991.

81. Chmieliński L., Kapłan jako stuga Słowa Bożego. Studium „Listów” św. Grzegorza Wielkiego, 1992.

82. Gałuszka J., Charyzmatycy w pismach Ojców Apostolskich, 1992.

83. Dychto J., Eschatologiczny aspekt najstarszej homilii chrześcijańskiej czyli tak zwanego „Drugiego Listu do Koryntian św. Klemensa”, 1992.

84. Gil J., Chrzest w przepowiadaniu pielgrzymkowym Jana Pawła II na ziemi polskiej, 1992.

85. Jezienicki W. OP, Chrystus i Kościól droga do Ojca wedtug św. Augustyna. Studium „Homilii na Ewangelię i Pierwszy List św. Jana”, 1992.

86. Kalinowski L., Chrześcijańskie podejście do modlitwy w kazaniach biskupa Tihamera Totha na temat „, Ojcze nasz”, 1992.

87. Kwiecień T., Sakramenty chrześcijańskiego wtajemniczenia w ujęciu świętego Ambrożego z Mediolanu, 1992.

88. Pędzimąż R., Tajemnica Chrystusa w „Homiliach na rok A” księdza biskupa Jana Pietraszki, 1992.

89. Wielgus J., Kapłan jako sługa Stowa Bożego na podstawie traktatu św. Ambrożego „, Obowiązi duchownych”, 1992.

90. Iwanek P., Nauka Świętego Rafała Kalinowskiego o Matce Bożej w jego konferencjach, 1993.

91. Dobrzyński A., Sakramenty wtajemniczenia chrześcijańskiego w ujęciu świętego Cypriana Biskupa Kartaginy, 1993.

92. Dworakowski I., Duchowy portret świętego Ignacego z Antiochii, 1993.

93. Gołaski W., Wykład o wierze, charyzmatach $i$ miłości $w$ komentarzach Ambrozjastra i Pelagiusza do 12 i 13 rozdziału I Listu św. Pawła do Koryntian. Studium porównawcze, 1993.

94. Stachura M., Ocena religii pogańskiej w ujęciu św. Augustyna w „, De civitate Dei”, 1993.

95. Stryczek J., Koncepcja dialogu człowieka z samym sobą w ujęciu św. Augustyna na podstawie „, Pism filozoficznych”, 1993.

96. Zyzak W., Świat doczesny i jego wartość $w$ dialogach filozoficznych św. Augustyna, 1993. 
97. Rackowiak L. SDS, Przestrogi przed zagrożeniami na drodze realizacji kapłańskiego powołania w przepowiadaniu ks. Celestyna Józefa Rogowskiego SDS (1902-1988), 1993.

98. Burandt K.R. OP, Nauka o chrzciew „Objaśnieniach Psalmów” św. Augustyna, 1994.

99. Dziekan T.L. CSSF, Nauka o wadach moralnych w homiliach św. Bazylego Wielkiego, 1994.

100. Czerwień J., Wątek ascetyczno-mistyczny w „Homiliach o Modlitwie Pańskiej” św. Grzegorza z Nyssy, 1994.

101. Delik W. OP, Tajemnica wcielenia i zbawienia w ,Wielkiej Katechezie” św. Grzegorza z Nyssy, 1994.

102. Dziubek J., Godność człowieka w „,Wielkiej Katechezie” św. Grzegorza z Nyssy, 1994.

103. Gurgul S. OP, Wezwanie do świętości życia w ujęciu Andrzeja Floriana Gmurowskiego OP († 1944), 1994.

104. Faliński R., Chrzest, bierzmowanie i Eucharystia jako misteria wtajemniczenia chrześsijańskiego $w$,Katechezach mistagogicznych” św. Cyryla Jerozolimskiego, 1994.

105. Jędrzejewski W. OP, Nauka o przebaczeniu w „Listach” św. Cypriana, 1994.

106. Mateja L., Tajemnica Jezusa Chrystusa ukazana w „Homilii Paschalnej” Melitona z Sardes, 1994.

107. Matoga R., Aspekt dogmatyczny wykładu Modlitwy Pańskiej św. Grzegorza z Nyssy, 1994.

108. Mencfel M.F. CSSF, Świadectwa chrześcijańskiej wiary podane przez Sozomena w jego „Historii Kościoła”, 1994.

109. Mozdyniewicz P., Sakramenty wtajemniczenia chrześcijańskiego w ujęciu św. Grzegorza z Nyssy w „, Wielkiej Katechezie”, 1994.

110. Sochacka J.P. CSSF, Chrześcijanin wobec dóbr doczesnych wedtug Klemensa Aleksandryjskiego iśw. Bazylego Wielkiego. Studium porównawcze, 1994.

111. Stanuszek R., Pozytywne treści kultury pogańskiej w ujęciu Teodoreta z Cyru. Studium traktatu ,O leczeniu chorób hellenizmu”, 1994.

112. Wojciechowska J.J. CSSF, Koncepcja wychowania w ujęciu św. Jana Chryzostoma i św. Hieronima. Studium porównawcze, 1994.

113. Zelek J. Ocist., Poznawalność Boga wedtug św. Grzegorza z Nazjanzu, 1994.

114. Bielawski K., Literackie i teologiczne aspekty homilii świętego Jana Chryzostoma o świętym Ignacym Antiocheńskim, 1995.

115. Cebula K., Wartości matżeństwa wedtug św. Augustyna na podstawie dzieła „De bono coniugali”, 1995.

116. Karnas K., Nauka o przebaczeniu i pojednaniu w traktacie św. Augustyna „O kazaniu Pana na Górze”, 1995. 
117. Krisztopik T., Środki kaznodziejskie w homiliach moralnych św. Bazylego Wielkiego, 1995.

118. Kurysz M.A., Argument patrystyczny w dziele „, Religia Katolicka” bł. biskupa Józefa Sebastiana Pelczara, 1995.

119. Małodobry G., Nauka o pokusie i grzechu w traktacie św. Augustyna „O kazaniu Pana na Górze”, 1995.

120. Socha M., Nauka świętego Augustyna o Izraelu i o Kościele w „Problemach ewangelicznych", 1995.

121. Gonciarz J. OP, Obrona i wykład nauki o Wcieleniu w Liście św. Cyryla Aleksandryjskiego do Teodozjusza II „, O prawdziwej wierze”, 1996.

122. UniwersałA., Opatrzność Boża i wolność człowieka w „Filokalii” Orygenesa, 1996.

123. Bujak K. OP, Ideat duszpasterza - na podstawie komentarza św. Hieronima do Listu św. Pawła Apostoła do Tytusa, 1997.

124. Bartkowski A., Wątki historyczne $i$ teologiczne $w$ „,Mowie na zgon Teodozjusza” wygłoszonej przez św. Ambrożego, 1997.

125. Biernat J., Święty Antoni Pustelnik jako mąż ascezy i jej nauczyciel, 1997.

126. Czauderna Sz., Wezwanie do nawrócenia w „Pierwszym Liście do Koryntian” św. Klemensa Rzymskiego, 1997.

127. Iskra A. CSSF, Asceza anachoretów syryjskich. Studium traktatu Teodoreta z Cyru „Dzieje miłości Bożej”, 1997.

128. Janus M.Z.B. CSSF, Obrazowy sposób przedstawiania prawd wiary w ,Pasterzu” Hermasa, 1997.

129. Pilarczyk T., Obrazowy sposób przedstawiania godności chrześcijanina w „Katechezach chrzcielnych” św. Jana Chryzostoma, 1997.

130. Sikora P., Przebóstwienie człowieka w wybranych mowach św. Grzegorza z Nazjanzu, 1997.

131. Małodobry A., Chrześcijańskie podejście do prawa. Studium traktatu Tertuliana „Przeciw Żydom”, 1997.

132. Zięba Z., Koncepcja chrześcijańskiego teologa wedtug świętego Wincentego z Lerynu, 1997.

133. Biskup M. OP, Koncepcja katechizmu na podstawie „, Wielkiej Katechezy” świętego Grzegorza z Nyssy, 1998.

134. Bączek P., Bogactwo chrystologii dwóch pierwszych rozdziałów Listu do Hebrajczyków w ujęciu Klemensa Aleksandryjskiego, 1998.

135. Budka Z., Symbolika drzewa poznania dobra i zła oraz drzewa życia w pismach egzegetycznych przeciwko manichejczykom św. Augustyna, 1998.

136. Gadocha A., Biskup wobec problemów społeczno-gospodarczych. Studium „Listów” Teodoreta z Cyru, 1998.

137. Kowal S.A. CSSF, Portrety świętych biskupów Ambrożego i Augustyna w ujęciu ich pierwszych biografów, 1998.

138. Mizgała Z.M. CSSF, Modlitwa Ojców Pustyni. Studium traktatu „,Dzieje miłości Bożej” Teodoreta z Cyru, 1998. 
139. Nowicki S., Podejście do pijaństwa Filona Aleksandryjskiego i św. Bazylego Wielkiego. Studium porównawcze, 1998.

140. Trzopek P. OP, Zasady interpretacji Pisma Świętego i ich wykorzystanie wedtug Orygenesa, 1998.

141. Skowroński J., Dalsze i bliższe przygotowanie do Eucharystii na podstawie „Kazań Eucharystycznych” Stugi Bożego Księdza Biskupa Jana Pietraszki, 1998.

142. Stańczyk M.A. CSSF, Koncepcja katechizmu wedtug św. Cyryla Jerozolimskiego i św. Augustyna. Studium porównawcze, 1998.

143. Synowiec A., Kształtowanie wrażliwości sumienia. Studium traktatu św. Jana Chryzostoma „, O wychowaniu dzieci”, 1998.

144. Szkółka Z., Teologiczna tematyka „Listów paschalnych” Teofila Aleksandryjskiego, 1998.

145. Wojtulewicz A. OSB, Życie samotne a życie wspólnotowe w „Regułach” św. Bazylego Wielkiego, 1998.

146. Babiarz G., Bohaterki życia ascetycznego. Studium „Historia Lausiaca” Palladiusza, 1999.

147. Jamroziński W., „Ojcze, święć się imię Twoje”-w ujęciu Wschodnich i Zachodnich Ojców Kościoła, 1999.

148. Kabala Z. OSU, Wychowanie dojrzałego chrześcijanina w ujęciu Orygenesa na tle starożytnych koncepcji wychowania, 1999.

149. Kiszczak M., , Ojcze, odpuść nam nasze winy, jako i my odpuszczamy naszym winowajcom" - w ujęciu św. Augustyna, 1999.

150. Króżel K., Rzeczy ostateczne i ich wpływ na życie człowieka w pismach ascetycznych oraz homiliach i kazaniach św. Bazylego Wielkiego, 1999.

151. Lill-Bezak A., Nauka św. Grzegorza Teologa o Opatrzności Bożej, 1999.

152. Przechowski G. OP, Portret kaznodziei w ujęciu św. Ambrożego z Mediolanu $i$ św. Jana Chryzostoma. Studium dziet „, Obowiazki duchownych ” $i$ „,Dialog o kapłaństwie”, 1999.

153. Smyrak M., Homiletyczne zasady interpretacji Pisma Świętego wedtug św. Augustyna, 1999.

154. Sordyl K., Bóg i tajemnica człowieka. Studium ,, Wykładu wiary prawdziwej” Jana z Damaszku, 1999.

155. Woźniak R., Teologiczne podstawy kultu ikon i świętych. Studium ,, Wykładu wiary prawdziwej”'św. Jana z Damaszku, 1999.

156. Wojdyła M. F., Miłosierdzie Boga i ludzi. Studium „Mów” Grzegorza z Damaszku, Częstochowa 1999.

157. Krutak J., Tajemnica Wcielenia $w$ ujęciu św. Cyryla Jerozolimskiego $i$ św. Grzegorza z Nyssy. Studium porównawcze, 2000.

158. Lenart M., Pierwszy rozdziat Listu św. Pawła Apostoła do Rzymian w interpretacji Jana Chryzostoma i Teodoreta z Cyru. Studium porównawcze, 2000.

159. Orszulik J., Tajemnica Wcielenia w ujęciu Ojców Apostolskich, 2000. 
160. Waleczek L., „, Ojcze, bądź wola Twoja jako w niebie taki na ziemi” w interpretacji łacińskich Ojców Kościoła, 2000.

161. Zięba K., Pedagogiczny wymiar ,,Tradycji Apostolskiej” Hipolita Rzymskiego, 2000.

162. Jadłosz M., Nauka o nawróceniu w pismach św. Cypriana, 2001.

163. Gaj T. OP, Nauka o pokorze Mistrzów Pustyni. Studium pism Starców spod Gazy, 2002.

164. Bętkowski M., Droga przemiany życia w oparciu o łaskę chrztu świętego. Studium , Katechez chrzcielnych” św. Jana Chryzostoma, 2002.

165. Nesterowicz J. OP, Przyjaźń w rozumieniu św. Jana Chryzostoma $i$ św. Augustyna. Studium traktatów „, O kapłaństwie” i „, Wyznañ”, 2002.

166. Palej P., Charyzmatyczne ojcostwo. Studium „Apoftegmatów” Ojców Pustyni, 2002.

167. Romanowski P., Elementy racjonalno-dyskursywnej motywacji za istnieniem Boga w „, Confessiones” św. Augustyna, 2002.

168. Wala T., Chrystusowe wypowiedzi o poście w Ewangeliach synoptycznych w interpretacji Ojców Kościoła pierwszych trzech wieków, 2002.

169. Wysogląd M., Rozumienie modlitwy w interpretacji św. Grzegorza z Nyssy, 2002.

170. Dziki K., Mądrość i głupota. Studium Komentarza św. Hieronima do Ksiegi Eklezjastesa, 2003.

171. Glonek J., Ojcowie Kościoła o czci dla Eucharystii i warunkach jej przyjmowania, 2003.

172. Wolczko M., Obrazowe ujęcie prawd wiary i moralności. Studium „Uczty” św. Metodego z Olimpu, 2003.

173. Przybyła Ł., Ideał duchownego w „Listach” św. Hieronima, 2003.

174. Broniek R. OP, Praktyka ascetyczna jako duchowa droga do Boga. Studium traktatu „Practicus” Ewagriusza z Pontu, 2003.

175. Adamski M. OP, Napięcia między Kościołem Wschodnim i Zachodnim. Studium „Listów” św. Bazylego Wielkiego, 2003.

176. Fajfer S., Teologiczna treść w tekstach modlitw Maryi w Ewangeliach apokryficznych, 2004.

177. Kudzia R., Mądrość i miłosierdzie. Studium Homilii św. Jana Chryzostoma na Listy św. Pawła Apostoła do Rzymian, 2004.

178. Hosaja M., Kościót jako owczarnia Chrystusa. Studium Homilii św. Augustyna o Dobrym Pasterzu na Ewangelię św. Jana (J 10, 1-20), 2004.

179. Tarasiuk A., Rodzinny wymiar życia ewangelicznego. Studium Homilii św. Jana Chryzostoma na Listy Pasterskie św. Pawła i na List do Filemona, 2004.

180. Baloh S. OP, Wypetnienie Prawa. Studium „Homilii św. Jana Chryzostoma na Ewangelię wedtug św. Mateusza”, 2004.

181. Popko Ł. OP, Cesarze wobec zgromadzeń biskupów. Studium „Historii Kościoła” Hermiasza Sozomena, 2004. 
182. Kuczko N. OP, Chrześcijanin wobec ataków szatana. Studium „Homilii Jana Chryzostoma na Ewangelię wedtug św. Mateusza", 2004.

183. Małkiewicz Ł., Nauka o pokucie. Studium Listów św. Bazylego Wielkiego i dziet św. Pacjana z Barcelony, 2004.

184. Baran P., Tajemnica kapłaństwa. Studium Komentarza Listu do Hebrajczyków Teodoreta z Cyru, 2005.

185. Kozina M., Cierpienie $i$ doświadczenie $w$ życiu chrześcijanina. Studium „Homilii Jana Chryzostoma na Ewangelię wedlug św. Mateusza”, 2005.

186. Dębski K., Wiara w ujęciu św. Jana Chryzostoma. Studium „Homilii Jana Chryzostoma na Ewangelię wedlug św. Mateusza", 2005.

187. Jagieła W., Sylwetka Piotra. Studium „Homilii Jana Chryzostoma na Ewangelię wedtug św. Mateusza”, 2005.

188. Kurnik K., Obrzędy liturgii eucharystycznej w interpretacji św. Cyryla Jerozolimskiego i św. Ambrożego. Studium porównawcze, 2006.

189. Kościk K., Obrzęd i teologia chrztu i bierzmowania w interpretacji Cyryla Jerozolimskiego i św. Ambrożego z Mediolanu, 2006.

190. Medwid W., Chrzest Chrystusa w interpretacji patrystycznej, 2006.

191. Sala R., Kościół a władza świecka. Studium komentarzy patrystycznych do Listu św. Pawta do Rzymian 13 1-7, 2006.

192. Studnicki P., Nauka Jana Chryzostoma o matżeństwie. Studium „Homilii na Ewangelię wedtug św. Mateusza", 2006.

193. Błażejowski T., Wolna wola i wolność. Studium „Wyznań” św. Augustyna, 2007.

194. Gałuszka P., Sens pracy fizycznej w życiu mnichów w ujęciu św. Bazylego Wielkiego i św. Augustyna, 2007.

195. Młynarczyk R., Osiem Błogosławieństw. Studium porównawcze „XV Homilii na Ewangelię wedtug św. Mateusza” św. Jana Chryzostoma i traktatu ,O kazaniu Pana na Górze" św. Augustyna, 2007.

196. Kucharczyk K., Misterium nieprawości. Studium „Homilii na Ewangelie” św. Grzegorza Wielkiego, 2007.

197. Kasprzak K., Pojęcie Boga. Studium „Zachęty do Greków” Klemensa Aleksandryjskiego, 2007.

198. Piechowicz K., Uwolnienie opętanych. Studium porównawcze „, Komentarza do Ewangelii św. Mateusza” "św. Hilarego z Poitiers oraz „Homilii na ewangelię wedlug św. Mateusza" św. Jana Chryzostoma, 2007.

199. Moskal J., Odpowiedzialność duchownych. Studium „Księgi reguly pasterskiej" Grzegorza Wielkiego, 2007.

200. Okoński M. OP, Godność chrześcijanina. Studium porównawcze „Wielkiej katechezy” Grzegorza z Nyssy i „Podręcznika dla Wawrzyńca” Augustyna z Hippony, 2007.

201. Wróbel P.J., Troska o duchowieństwo. Studium dokumentów prawnych starożytnych Soborów Konstantynopol II, Konstantynopol III, Nicea II, 2008. 
202. Popielarczyk D., Troska o duchowieństwo. Studium starożytnych soborów pierwszych pięciu wieków, 2008.

203. Kruszak M., Abraham ojciec wierzacych. Studium Komentarzy do Listu św. Pawta do Rzymian Pelagiusza i Teodoreta z Cyru, 2008.

204. Smalcerz T., Odpowiedzialność Kościoła za mnichów. Studium kanonów soborów starożytnych, 2008.

opracował ks. Franciszek Ślusarczyk 
